\title{
Összefonódott fotonpár források fejlesztése
}

\author{
Sarkadi Tamás ${ }^{1}$, Holló Csaba ${ }^{1}$, Erdei Gábor ${ }^{1}$, Barócsi Attila ${ }^{1}$, Galambos Máté1, Koppa \\ Pál ${ }^{1}$ \\ ${ }^{1}$ Budapesti Müszaki és Gazdaságtudományi Egyetem, Atomfizika Tanszék, 1111 Budapest, Budafoki \\ út 8.
}

DOI: https://doi.org/10.14232/kvantumelektronika.9.29

\section{Bevezetés}

A kvantumoptika a fotonika gyorsan növekvő ága, amely a kvantumszámítások, a telekommunikáció, valamint titkosító kulcsok megosztására alkalmas eszközök és módszerek megvalósítását célozza. [1] A kvantumoptikai távközlő rendszerek egyik legfontosabb eleme a fényforrás, amely összefonódott fotonpárokat bocsát ki. [2] Az alkalmazott fotonpárok leggyakrabban energia-idő összefonódással, vagy polarizációban megvalósuló összefonódással rendelkeznek. Munkánk célja, hogy polarizációban összefonódott, $810 \mathrm{~nm}$ hullámhosszú fotonpárokat előállító forrásokat fejlesszünk, melyek szabadtéri kvantumoptikai távközlő és kulcsmegosztó rendszerekben hatékonyan alkalmazhatóak. Célunk, hogy robosztus, hordozható, és az alkalmazás számára elegendő fotonfluxust előállító forrást hozzunk létre.

Az összefonódott fotonpárok előállítására leggyakrabban a spontán parametrikus lekonverzió (SPDC) jelenségét használják fel, mely nemlineáris optikai kristályokban zajlik le. A pumpálásra használt fény fotonja alakul át egy fotonpárrá, melynek összenergiája a pumpafoton energiájával egyezik meg. A kristály anyaga leggyakrabban béta bárium borát (BBO), vagy periodikusan polarizált kálium titanil foszfát (ppKTP) [3] Ez utóbbi használatakor a kristály hőmérsékletét stabilizálni kell. Ennek elkerülése érdekében a jelenlegi munkánk során BBO kristályt használtunk. A BBO kristályok két típusával foglalkoztunk. Az I. típusú $\mathrm{BBO}$ kristályt extraordinárius polarizációjú pumpafénnyel kell gerjeszteni, a lekonvertált fotonok ordinárusak, és jellemzően egy kúppalást mentén detektálhatóak nagy valószínüséggel. A II. típusú kristályból kilépő lekonvertált fotonpárok egyike ordinárius, másika extraordinárius polarizációjú. A kristályt elhagyó fotonok két egymást metsző kúppalást mentén terjednek. A kúpok két közös alkotójában a detektálható fotonok polarizációban összefonódottak és Bell-állapotban vannak [4], ami jól használható titkosító kulcsok megosztására.

Jelen cikkünkben bemutatjuk, milyen körülmények között használható a II. típusú BBO kristály Bell-állapotú, polarizációban összefonódott fotonok elöállítására. Bemutatjuk fáziskompenzáló módszerünket, mellyel az összefonódottság bázisfüggetlen láthatósága javítható. Bemutatjuk a fáziskompenzált fényforráson elvégzett Bell-teszt eredményeit. Beszámolunk továbbá egy I. típusú kristállyal müködő kompakt fotonpár forrás fejlesztésében elért eredményeinkröl is.

\section{Fáziskompenzáció alkalmazása összefonódott fotonpár forrásban}

Felépítettünk egy II. típusú BBO kristályon alapuló, polarizációban összefonódott fotonokat előállító fényforrást. (1.ábra) A rendszer folytonos üzemü, egymódusú (módusstabilizált) pumpalézerrel rendelkezik, melynek közép-hullámhossza $405 \mathrm{~nm}$. A HWP $\lambda / 2$ lemez elforgatásával beállítható a beeső pumpa polarizációja az SPDC folyamatot megvalósító nemlineáris kristályon (BBO), Az $\mathrm{F}$ sávszürő $(810 \mathrm{~nm}$ közép-hullámhossz, $10 \mathrm{~nm}$ 
sávszélesség) a pumpanyaláb elnyomására szolgál. Az általunk vizsgált összefonódott állapotok iránya $\pm 5^{\circ}$. Mindkét karon az $\mathrm{A}$ apertúra $0,1^{\circ} \times 0,1^{\circ}$ polár- és azimut-szögeknek felel meg és meghatározza a beállítás szögfelbontását. Az állapotok elemzéséhez az egyes karokba helyezett P1 és P2 lineáris polarizátorokat használtuk, a z-tengelytől mért szögekkel. Az L lencsék az F2 647 nm-es hosszúhullámú élszürőkön át fókuszálják az SPDC fényt az egyfoton-detektorokra (SPAD). A fáziskompenzátor elemek (BC kettőstörő kristály és Berekkompenzátor) a fotonállapotok közötti fáziskülönbség durva és finomhangolására szolgálnak. A detektorjeleket koincidencia számláló áramkör segítségével dolgozzuk fel.
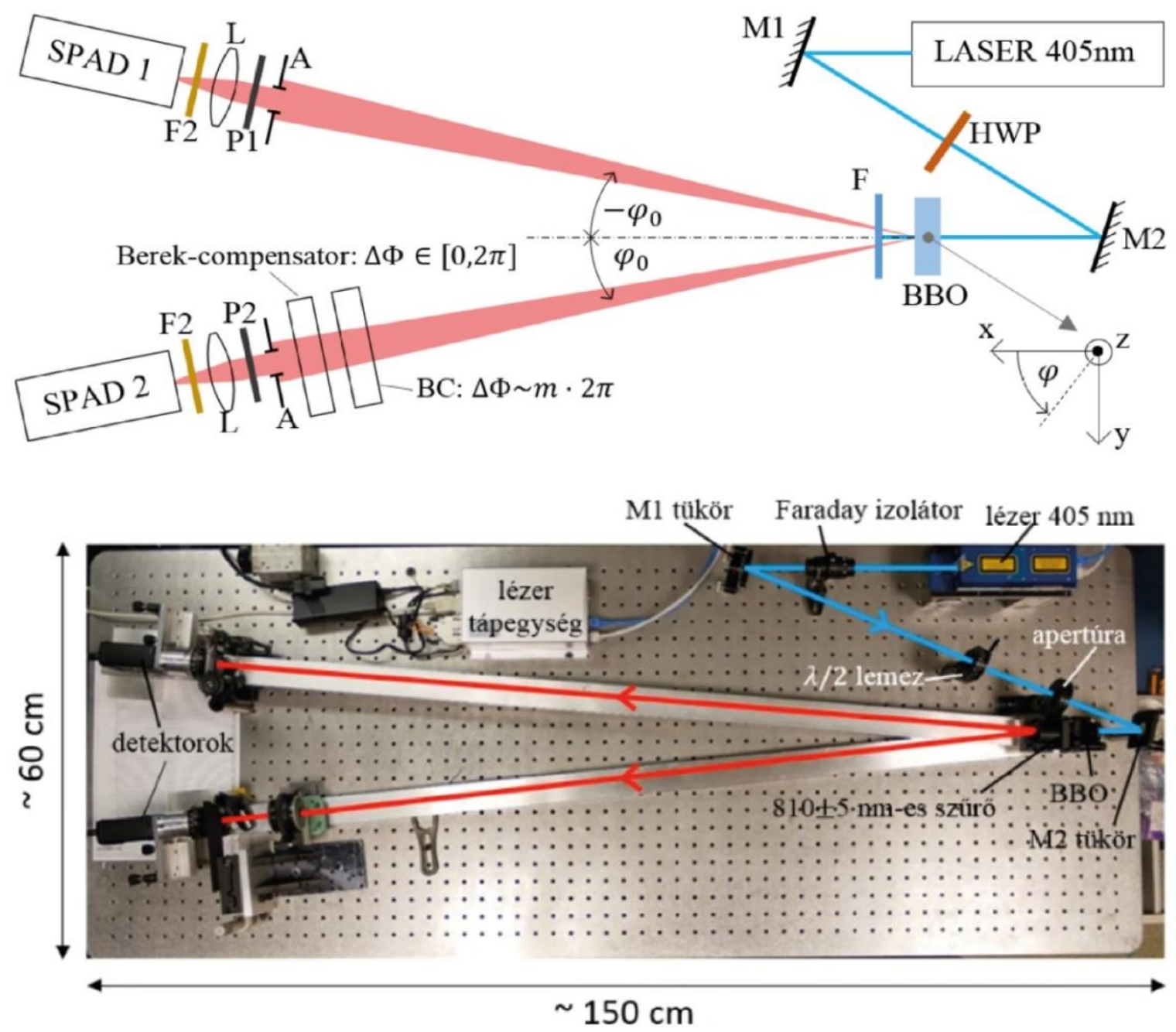

1. ábra. BBO kristállyal megvalósított fotonpár forrás kísérleti elrendezése.

A kísérletben az SPDC jelenség összefonódott és szorzat állapotok keverékét eredményezi. Még ha az összefonódott állapotok valószínüsége nagyon magas is, nem feltétlenül képezik a kívánt Bell-állapotot. A kettőstörő SPDC anyagok fáziskülönbséget mutatnak a HV és VH polarizációs állapotok között (H: vízszintes, V: függőleges). Ha a kristályból kilépő ordinárius és extraordinárius hullámkomponensek fáziskülönbsége nagyobb, mint a keletkezett fény koherencia hossza, akkor a fotonállapotok nem interferálnak. Ennek nincs hatása $0^{\circ}$ és $90^{\circ}$ bázisválasztás esetén, de az összefonódott párok közötti korreláció csökkenését eredményezi $45^{\circ}$ bázis esetén. Ideális esetben a $45^{\circ}$ bázis és a $\left(0^{\circ} ; 90^{\circ}\right)$ bázis koincidencia-arányát a fotonpárok spektrális sürüség-eloszlásának Fourier-transzformációjával a Wiener-Khinchin tétel alapján számolhatjuk [5] (2. ábra jobbra fent). A spektrális sürüség-eloszlás pedig a BBO 
utáni $\mathrm{F}$ sávszürő (1. ábra fent) átvitele határozza meg, amelyet megmértünk és numerikusan transzformáltunk (2. ábra balra fent).
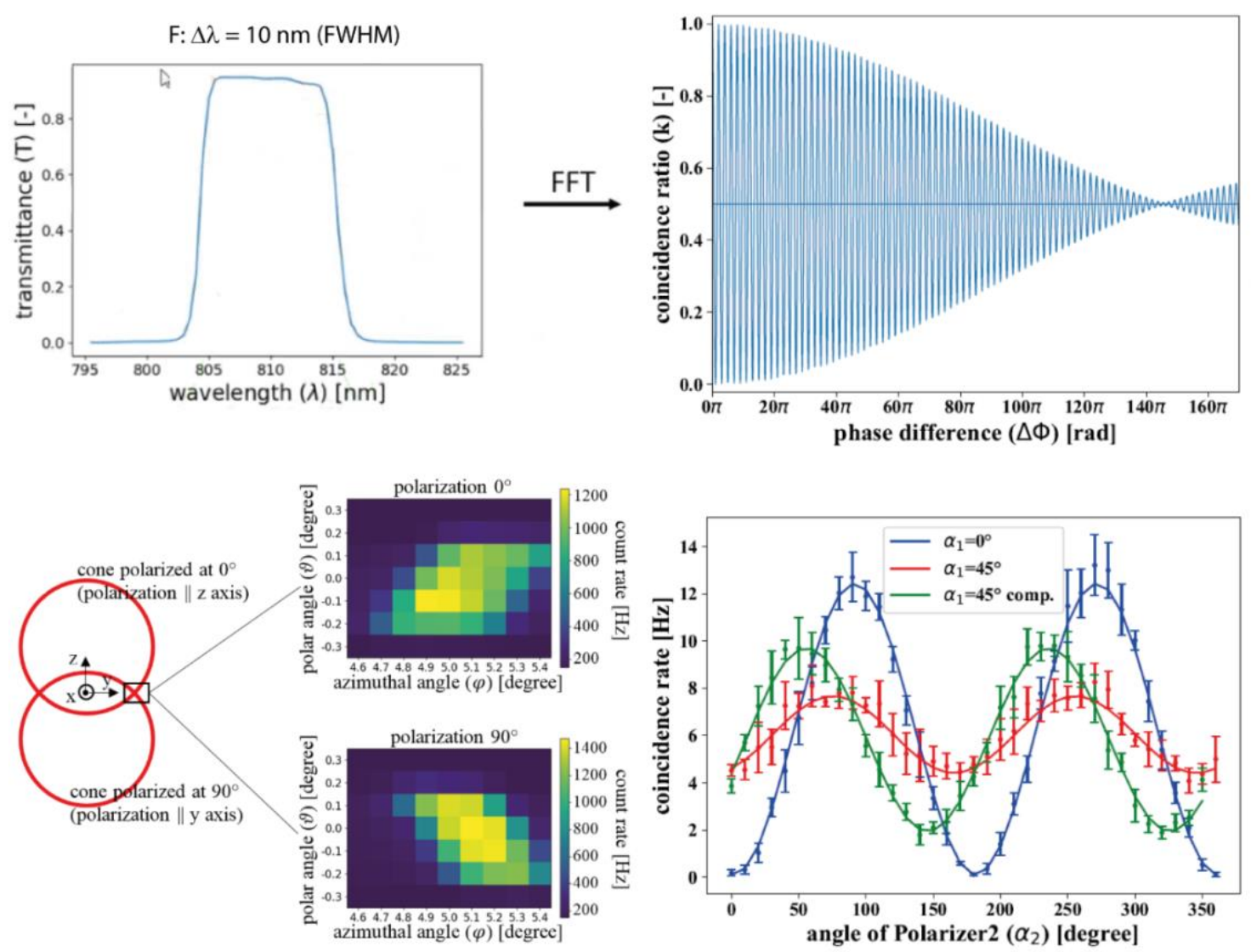

2. ábra. II-típusú BBO-val előállított összefonódott állapotok vizsgálata. Felső sor: a goniométeres elrendezés BBO utáni F sávszürőjének spektrális átvitele (balra fent) és Fouriertranszformáltja a fotonpárok koincidencia-arányainak becsléséhez (jobbra fent) a fáziskülönbség függvényében $\left(45^{\circ}\right.$-os polarizátor-beállítások esetén). Balra lent: II-típusú BBO SPDC fotonpárjainak kilépő kúpjai és azok apertúrával mintavételezett átfedési tartományában kapott beütésszámok. Jobbra lent: koincidecia-beütésszámok a 2. polarizátor szögének függvényében. A folytonos vonalak az illesztett koszinusz függvények: a kék / piros görbék esetén a fotonpárokat kompenzálás nélkül mértük, míg a zöld görbét a fotonállapotok között elérhető legjobb fáziseltolás beállításával.

A fázistolást kompenzálhatjuk úgy, hogy kettőstörő elemeket (BC és Berek-kompenzátor) helyezünk az egyik karba (1. ábra fent). BC-ként egy másik, az SPDC BBO-val azonos kettőstörést adó BBO-t alkalmaztunk. A szükséges késleltetés beállításához a BC optikai tengelyét a 2. kar tengelyéhez képest megdöntöttük. A finomhangolást a Berekkompenzátorral végeztuik úgy, hogy maximális koincidencia-beütésszámot kapjunk $45^{\circ}$ bázis esetén is (2. ábra jobbra lent). A nem kompenzált $0,27 \pm 0.013$ és a kompenzált $0,67 \pm 0.025$ láthatósági értékek sem érik el az 1 elméleti korlátot (a $0^{\circ}$ bázist is ábrázoltuk referenciaként), de a megfigyelt növekedés meggyőző. A gyenge láthatóság magyarázata lehet, hogy a fázisszög még mindig nem optimális, illetve több paraméter (pl. apertúra-méret) még nincs optimalizálva. Ugyanakkor láthatóan a polarizációban összefonódott fotonpárok korrelációjának növelésére a fázistolás kompenzálás hatékony módszer és segíthet növelni ezen fotonok hasznos spektrális tartományát nagyobb koincidencia-beütésszámot eredményezve. 


\section{A fotonforrás Bell-tesztje}

A mérés célja, hogy vizsgáljuk az előző fejezetben bemutatott ikerfoton-forrás két, térben elválasztott ágában kilépő fotonpár polarizációs állapotának erős kvantum-összefonódását, ezzel is minősítve a forrás kvantumos viselkedését. A Bell-féle „rejtett változós elmélet” és az ennek megfelelő matematikai egyenlőtlenséget a Clauser, Horne, Shimony és Holt által bevezetett „S” paraméterrel [6] és annak hibájával minősítettük és hasonlítottuk össze annak kvantumelméleti értékével.

A rendszer hangolása után a detektorok elé helyezett polarizátorok négy beállítása mellett történtek mérések. Az egyes $\alpha$ és $\beta$ polarizátorbeállítások mellett mért koincidencia beütésszámokat a $P_{H V}(\alpha, \beta), P_{V H}(\alpha, \beta), P_{H H}(\alpha, \beta)$, és $P_{V V}(\alpha, \beta)$ szimbólumok jelölik. Ha az adott mérés során a megfelelő detektor előtti polarizátor az argumentumban szereplő szögben állt, $H$ indexszel, ha arra merölegesen, $V$ indexszel jelöltük [7] nyomán. Ezek segítségével definiáljuk a következő méröszámokat:

$$
\begin{gathered}
E(\alpha, \beta)=P_{H V}(\alpha, \beta)+P_{V H}(\alpha, \beta)-P_{H H}(\alpha, \beta)-P_{V V}(\alpha, \beta) \\
S=E(a, b)-E\left(a, b^{\prime}\right)+E\left(a^{\prime}, b\right)+E\left(a^{\prime}, b^{\prime}\right)
\end{gathered}
$$

ahol $\left\{a, a^{\prime}, b, b^{\prime}\right\}$ négy különböző polarizációs beállítás. Az így bevezetett mennyiségek jelentősége abban áll, hogy bármely rejtett paraméteres elmélet szerint tetszőleges polarizátor beállításokra $|S| \leq 2$. Az első polarizátort $\alpha=\left\{22,5^{\circ} ; 67,5^{\circ} ; 112,5^{\circ} ; 157,5^{\circ}\right\}$ állásban, míg a másodikat $\beta=\left\{0^{\circ} ; 45^{\circ} ; 90^{\circ} ; 135^{\circ}\right\}$ állásba forgatva mértük a 10 másodperces időablakba eső koincidenciákat. A kísérleti elrendezés begyüjtött adataival a Bell-tesztet nagyszámú mintára elvégezve a következő eredmény adódott:

$$
|S|=2,255 \pm 0,039
$$

vagyis a Bell-egyenlőtlenség megsértését több mint $6 \sigma_{S}$ bizonyossággal sikerült kimérni a felépített fotonforrásunk segítségével.

\section{Kompakt fotonpár forrás fejlesztése}

A fotonpár keltés kísérleti megvalósítása terén összegyült tapasztalataink alapján terveztünk egy I. típusú BBO kristályon alapuló fotonpár forrást, mely idő-energia alapú összefonódást valósít meg. A forrással szemben elvárásunk volt, hogy másodpercenként legalább 1400 darab 810 nm-es középhullámhosszú fotonpárt állítson elő úgy, hogy azok egymódusú optikai szálakba csatolva hagyják el a készüléket. Emellett az eszköz legyen hordozható kivitelü, továbbá költséghatékonyan felépíthető.

A tervezés során arra törekedtünk, hogy az SPDC folyamat során keletkező, kúppalást mentén terjedő fényhullám minél nagyobb hányadát minél nagyobb hatásfokkal lehessen az egymódusú szálakba csatolni úgy, hogy a pumpanyaláb fotonjai minél kisebb valószínüséggel jussanak be a szálakba. A becsatolási hatásfok megnövelése érdekében a kristály pumpált tartománya és a szálvégek között optikai leképezést valósítottunk meg. A leképezés nagyításának, a lencserendszer pupillaátméröjének optimalizálását, valamint a várható aberrációk minimalizálását ZEMAX optikai tervezőprogram segítségével végeztük. Az optimális leképezés nagyításának 1:2,1 érték adódott. A szálcsatoló optika belépő pupillájának és az SPDC folyamat során keletkező fény hullámfrontjának viszonyát a 3. ábra 
szemlélteti. A tervezett konfiguráció mellett 24,7 \% annak a valószínűsége, hogy az SPDC folyamat során keletkező fotonpár mindkét tagja szálba csatolódik.



3. ábra. A spontán parametrikus lekonverzió útján keletkező fény hullámfontjának távoltéri intenzitás-eloszlása (gyürü alakú eloszlás), valamint a pumpahullám intenzitás eloszlása (Gauss-eloszlás a gyürü közepén). A szálcsatoló rendszer optimális belépő pupillája (világos, Hold formájú körlap)

A tervezett készülék vázlatát a 4.a ábra mutatja, mely továbbfejlesztett változata az 1. ábrán látható elrendezésnek. Pumpafényforrásként (LD) egy 405 nm-es, egy transzverzális módussal rendelkező lézerdiódát alkalmaztunk, melyet stabilizált árammal hajtottunk meg. A dióda fényét nyalábformáló optikával (CL+BS) kollimáltuk, majd a nyalábot a kristály középpontjába fókuszáltuk. A pumpanyaláb megfelelő polarizációs állapotát félhullám lemezzel állítottuk elő. (HWP). A parametrikus lekonverzió $3 \mathrm{~mm}$ vastag I. típusú BBO kristályban valósul meg. A pumpanyalábot az $\mathrm{F}$ aluláteresztő szürő segítségével nyomjuk el. Az M tükrök részben a fényutak összehajtását, részben a terjedési irányok beállítását szolgálják. A szálcsatoló lencserendszer (LP) két akromátból áll, és 1:2 arányú leképezést valósít meg. A lencsék előtt található (A) apertúra a 3. ábrán látható alakú. A szálrögzítő foglalatok (FA) előtt található PP planparallel lemezek két tengely mentén dönthetőek, segítségükkel a lencsék fókuszfoltja a szálvégekre igazítható.

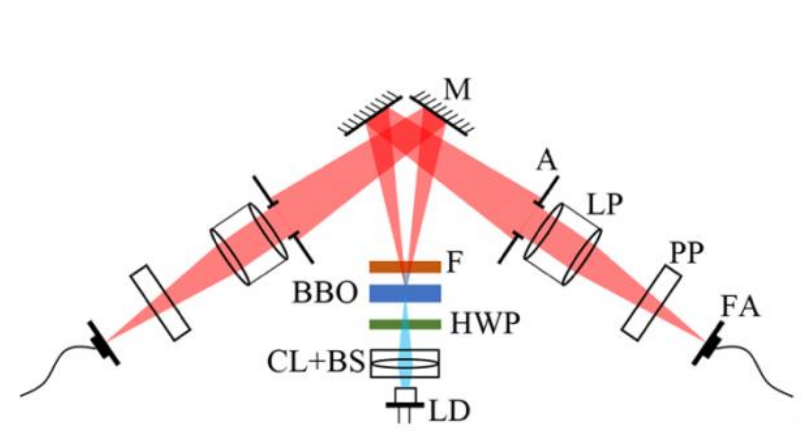

(a)

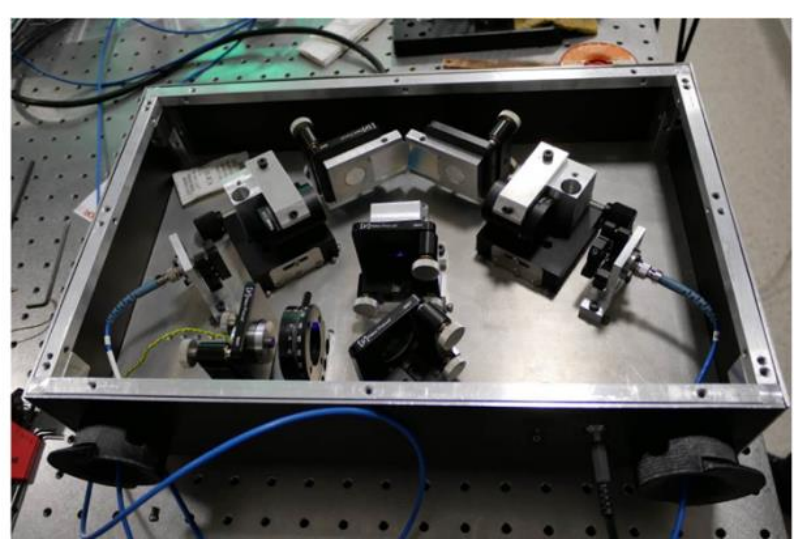

(b)

4. ábra. A kompakt összefonódott fotonpár forrás vázlatos elrendezése (a). Az elkészült fotonpár forrás (b).

Az optikai elemeket $20 \mathrm{~mm}$ vastag alumínium lemezre építettük a mechanikai stabilitás érdekében, amit aztán fénymentesen és hermetikusan lezárható dobozba helyeztünk. Az elkészült berendezés a 4.b ábrán látható. Optimális beállítások mellett a szálkimeneteket 
$5^{*} 10^{5}$ koincindens fotonpár hagyja el $46 \mathrm{~mW}$-os pumpalézer teljesítmény mellett, míg a heralding arány $21 \%$. A fotonpár forrás jelenlegi paraméterei alapján alkalmas arra, hogy szabadtéri kvantumoptikai távközlő rendszerben alkalmazzuk.

\section{5. Összefoglalás}

Munkánk során kísérletileg vizsgáltuk a béta bárium borát kristállyal megvalósított spontán parametrikus lekonverzión alapuló összefonódott fotonpár forrásokat. A kísérleti tapasztalatok alapján megterveztünk és megvalósítottunk egy szálcsatolt, energia-idő foton összefonódást létrehozó kompakt kivitelű fotonforrást. A közeljövőben a készüléket továbbfejlesztjük. A pumpanyaláb hullámhossz-stabilitása érdekében célszerünek látjuk a pumpalézer hőmérsékletének stabilizálását, továbbá a forrást alkalmassá tesszük polarizációban összefonódott fotonok előállítására.

\section{Köszönetnyilvánítás}

A kutatást a Nemzeti Kutatási Fejlesztési és Innovációs Alap támogatta a Nemzeti Kiválósági Program keretében, a "Kvantumbitek elóállítása, megosztása és kvantuminformációs hálózatok fejlesztése” címü, 2017-1.2.1-NKP-2017-00001. számú projekt részeként.

\section{Hivatkozások}

[1] M. Fox, Quantum Optics: An Introduction. Oxford U. Press, New York, 2006.

[2] A.K. Ekert, „Quantum cryptography based on Bell's theorem”, Physical Review Letters. 67 (6) 661-663 (1991)

https://doi.org/10.1103/PhysRevLett.67.661

[3] R. W. Boyd, Nonlinear Optics. Elsevier Science, 2008.

[4] J. S. Bell, „On the einstein podolsky rosen paradox,” Physics Physique Fizika, vol. 1, pp. 195-200, nov 1964.

https://doi.org/10.1103/PhysicsPhysiqueFizika.1.195

[5] E. Wolf, Introduction to the Theory of Coherence and Polarization of Light, Cambridge University Press, 2007.

[6] J.F. Clauser, M.A. Horne, A. Shimony, R.A. Holt, "Proposed experiment to test local hidden-variable theories", Phys. Rev. Lett., 23 (15): 880-4 (1969)

https://doi.org/10.1103/PhysRevLett.23.880

[7] D. Dehlinger and M. W. Mitchell, ,Entangled photons, nonlocality, and Bell inequalities in the undergraduate laboratory", Am. J. Phys., 70, 903-910 (2002)

https://doi.org/10.1119/1.1498860 